Design, Synthesis and Activity Against Human Cytomegalovirus of Non-Phosphorylatable Analogs of Toyocamycin, Sangivamycin and Thiosangivamycin*

Thomas E. Renau', Mary S. Ludwig' ${ }^{2}$ John C. Drach ${ }^{1,2}$ and Leroy B. Townsend ${ }^{*} 1,3$.

${ }^{1}$ Interdepartmental Program in Medicinal Chemistry, College of Pharmacy; ${ }^{2}$ Department of Biologic and Material Sciences, School of Dentistry; ${ }^{3}$ Department of Chemistry, College of Literature, Arts and Sciences, University of Michigan, Ann Arbor, Michigan 48109-1065.

(Received 30 September 1992)

\begin{abstract}
A number of 7-alkyl 4-aminopyrrolo[2,3-d] pyrimidine derivatives related to toyocamycin, sangivamycin and thiosangivamycin have been prepared and tested for their activity against human cytomegalovirus (HCMV). Only the thioamide substituted derivatives demonstrated biological activity.
\end{abstract}

Human cytomegalovirus (HCMV) infection is relatively benign in healthy individuals but can be debilitating or fatal to immunosuppressed individuals such as transplant recipients ${ }^{1}$ and AIDS patients. ${ }^{2}$ The drugs currently approved for the treatment of HCMV are ganciclovir (GCV, DHPG) ${ }^{3}$ and foscarnet (PFA). ${ }^{4}$ The clinical use of these compounds is limited because of host toxicity. ${ }^{5-6}$ In addition, there have been recent reports ${ }^{7-8}$ that strains of HCMV resistant to both drugs are emerging. Hence, there is a continued need to develop compounds which may circumvent the problems associated with the use of DHPG and PFA to treat HCMV infections.

The naturally occurring pyrrolo[2,3-d]pyrimidine nucleosides toyocamycin (1), sangivamycin (2) and a structurally related analog, thiosangivamycin $(3)$, possess significant activity against $\mathrm{HCMV}^{9-10}$<smiles>[R2]n1cc(Br)c2c(N)ncnc21</smiles>

1: $R_{1}=C N, R_{2}=B$-D-Riboturanose

3. $R_{1}=C_{S N H}, R_{2}=B$-D-Ribofuranose
2: $R_{1}=\mathrm{CONH}_{2}, \mathrm{R}_{2}=$ B-D-Ribofuranose

4: $\mathrm{R}_{1} \approx \mathrm{CSNH}_{2}, \mathrm{R}_{2}=\mathrm{CH}_{2} \mathrm{OCH}_{2} \mathrm{CH}_{2} \mathrm{OH}$

but are highly toxic to mammalian cells.9-12 Both toyocamycin and sangivamycin are phosphorylated by cellular adenosine kinase which ultimately leads to their toxicity in uninfected cells. ${ }^{13}$ In previous studies of sugar modified analogs of 1, 2 and 3,11-12,14-18 it was reported that acyclic analogs of 3 possesssed good activity against HCMV coupled with a significant reduction in cytotoxicity; ${ }^{11,} 14-15$ e.g., 4-amino-7-[(2-

* Portions of this study were presented at the $20^{\text {th }}$ American Chemical Society National Meeting (Medi \# 181), August 1992, Washington D. C. 
hydroxyethoxy)methyl]pyrrolo[2,3-d]pyrimidine-5-thiocarboxamide (4). ${ }^{14-15}$ Interestingly, similar acyclic analogs of 1 and 2 were also non-toxic but inactive against HCMV.11. 15 This suggested that the structural requirements of the substitutent at $N-7\left(R_{2}\right)$ may have less importance than the thioamide moiety at C-5 $\left(R_{1}\right)$ for the acyclic thiosangivamycin analogs to have activity against HCMV. If this is indeed the case, one might expect that a side chain hydroxyl group may not be essential for biological activity. In fact, recent studies have established that certain non-nucleoside analogs do have antiviral activity. ${ }^{19-21}$ To test our hypothesis, we have prepared several analogs of toyocamycin, sangivamycin and thiosangivamycin where the substituents at N-7 cannot be phosphorylated. In the present report, we describe the synthesis, antiviral activity and cytotoxicity of a number of model compounds.

Scheme I llustrates the synthetic route we used to prepare the non-nucleoside analogs. ${ }^{22}$ Compounds $7 \mathrm{a}$ and $7 \mathrm{~b}$ were prepared in a similar manner to that reported for $4^{14}$ from 2-amino-5-bromo-3,4-dicyanopyrrole $(5)^{23}$ in yields of 20 and $30 \%$, respectively. Treatment of $5^{23}$ with triethylorthoformate followed by the addition of sodium hydride and the appropriate alkylating agent gave the intermediate 6 which was not ssolated but

\section{SCHEME I}

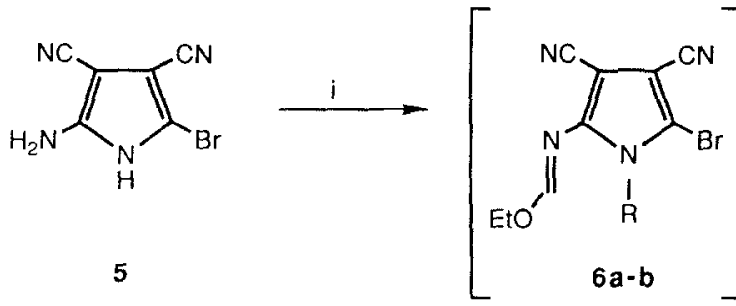<smiles>[R9]n1c(Br)c(C#N)c2c(N)ncnc21</smiles>

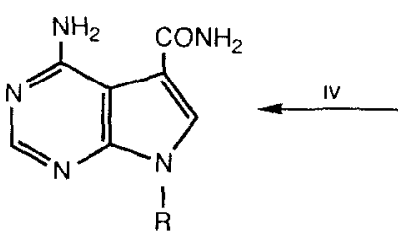

$9 a-c$

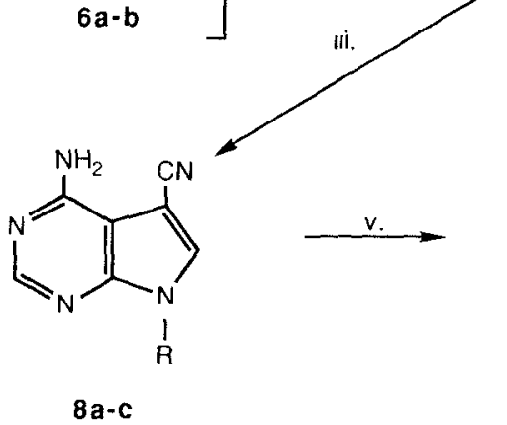

$8 a-c$<smiles>NC(=O)c1cn(P)c2ncnc(N)c12</smiles>

$10 a-c$
a. $\mathrm{R}=\mathrm{Me}$
b. $\mathrm{R}=\mathrm{CH}_{2} \mathrm{CH}=\mathrm{CH}_{2}$

c $\mathrm{R}=\mathrm{CH}_{2} \mathrm{CH}_{2} \mathrm{CH}_{3}$

1. 1) $\mathrm{CH}(\mathrm{OEt})_{3}, \mathrm{CH}_{3} \mathrm{CN}$; 2) $\mathrm{NaH}, \mathrm{RX}, \mathrm{CH}_{3} \mathrm{CN}$; ii. $\mathrm{NH}_{3} / \mathrm{MeOH}$;

1il. $\mathrm{H}_{2}, \mathrm{Pd} / \mathrm{C}$, EtOAc/EtOH or $\mathrm{Zn} / \mathrm{AcOH}$ (see text); iv $\mathrm{NH}_{4} \mathrm{OH} / \mathrm{H}_{2} \mathrm{O} / \mathrm{EtOH}, \mathrm{H}_{2} \mathrm{O}_{2}$.

$\checkmark \mathrm{MeOH}, \mathrm{H}_{2} \mathrm{~S} / \mathrm{NaOM}$

reacted directly with methanolic ammonia to afford the 7-substituted 4-amino-6-bromopyrrolo[2,3-ㅁ$]$ -

pyrimidine-5-carbonitriles (7a-b). The toyocamycin analogs $8 \mathbf{a}$ and $8 \mathbf{c}$ were obtained in $50-70 \%$ yields from $7 \mathbf{a}$ and $7 \mathbf{b}$, respectively, via catalytic hydrogenation whlle a selective reduction of $7 \mathbf{b}$ in zinc and acetic acid afforded 4-amino-7-(allyl)pyrrolo[2,3-d]pyrimidine-5-carbonitrile (8b) in a yield of $75 \%$. The carboxamides (9a-c) were synthesized from the appropriate compound 8 in $75-90 \%$ using $30 \%$ hydrogen peroxide in aqueous 
Table I: Antiviral activity and cytotoxicity of several 5,7-disubstituted 4-aminopyrrolo[2,3-d]-pyrimidines.

\begin{tabular}{|c|c|c|c|c|c|}
\hline \multirow[t]{2}{*}{ Compound } & \multicolumn{2}{|c|}{ Substituent } & \multicolumn{2}{|c|}{$\begin{array}{l}50 \% \text { Inhibitory Concentration } a \\
(\mu \mathrm{M})\end{array}$} & \multirow[b]{2}{*}{ SI } \\
\hline & $\mathbf{R}_{1}$ & $\mathrm{R}_{2}$ & HCMV & Growth $b, c$ & \\
\hline $\mathbf{1}^{d}$ & $\mathrm{CN}$ & $\beta$-D-Ribofuranose & 0.05 & $0.03^{e}$ & \\
\hline$f$ & $\mathrm{CN}$ & $\mathrm{CH}_{2} \mathrm{OCH}_{2} \mathrm{CH}_{2} \mathrm{OH}$ & $>100$ & $>100 g$ & \\
\hline$d$ & $\mathrm{CN}$ & $\mathrm{CH}_{2} \mathrm{OCH}\left(\mathrm{CH}_{2} \mathrm{OH}\right)_{2}$ & $>100$ & $>100 g$ & \\
\hline $8 \mathbf{a}$ & $\mathrm{CN}$ & $\mathrm{CH}_{3}$ & $>100$ & $>100$ & \\
\hline $\mathbf{8 b}$ & $\mathrm{CN}$ & $\mathrm{CH}_{2} \mathrm{CH}=\mathrm{CH}_{2}$ & $>100$ & $>100$ & \\
\hline $8 c$ & $\mathrm{CN}$ & $\mathrm{CH}_{2} \mathrm{CH}_{2} \mathrm{CH}_{3}$ & 36 & $>100$ & \\
\hline $2^{d}$ & $\mathrm{CONH}_{2}$ & $\beta$-D-Ribofuranose & 0.03 & $0.08 e$ & \\
\hline$f$ & $\mathrm{CONH}_{2}$ & $\mathrm{CH}_{2} \mathrm{OCH}_{2} \mathrm{CH}_{2} \mathrm{OH}$ & $>100$ & $>100 g$ & \\
\hline$d$ & $\mathrm{CONH}_{2}$ & $\mathrm{CH}_{2} \mathrm{OCH}\left(\mathrm{CH}_{2} \mathrm{OH}\right)_{2}$ & $>100$ & $>100 g$ & \\
\hline $9 \mathbf{a}$ & $\mathrm{CONH}_{2}$ & $\mathrm{CH}_{3}$ & $>100$ & $>100$ & \\
\hline $9 b$ & $\mathrm{CONH}_{2}$ & $\mathrm{CH}_{2} \mathrm{CH}=\mathrm{CH}_{2}$ & $>100$ & 90 & \\
\hline $9 \mathrm{c}$ & $\mathrm{CONH}_{2}$ & $\mathrm{CH}_{2} \mathrm{CH}_{2} \mathrm{CH}_{3}$ & $>100$ & 90 & \\
\hline 3 & $\mathrm{CSNH}_{2}$ & $\beta$-D-Ribofuranose & $0.19 \pm 0.2$ & 0.03 & $<1$ \\
\hline $4 f, h$ & $\mathrm{CSNH}_{2}$ & $\mathrm{CH}_{2} \mathrm{OCH}_{2} \mathrm{CH}_{2} \mathrm{OH}$ & $8.8 \pm 5.8$ & 115 & 13 \\
\hline$d$ & $\mathrm{CSNH}_{2}$ & $\mathrm{CH}_{2} \mathrm{OCH}\left(\mathrm{CH}_{2} \mathrm{OH}\right)_{2}$ & $6.2 \pm 5.1$ & $>100 g$ & \\
\hline $10 \mathbf{a}$ & $\mathrm{CSNH}_{2}$ & $\mathrm{CH}_{3}$ & $1.2 \pm 0.8$ & $14.7 \pm 6.0$ & 12 \\
\hline $10 \mathrm{~b}$ & $\mathrm{CSNH}_{2}$ & $\mathrm{CH}_{2} \mathrm{CH}=\mathrm{CH}_{2}$ & $2.1 \pm 1.9$ & $19.0 \pm 2.8$ & 9 \\
\hline $10 c$ & $\mathrm{CSNH}_{2}$ & $\mathrm{CH}_{2} \mathrm{CH}_{2} \mathrm{CH}_{3}$ & $1.2 \pm 0.7$ & $17.0 \pm 4.2$ & 14 \\
\hline \multicolumn{3}{|c|}{ Ganciclovir (DHPG) } & $8.4^{i}$ & $>100$ & \\
\hline
\end{tabular}

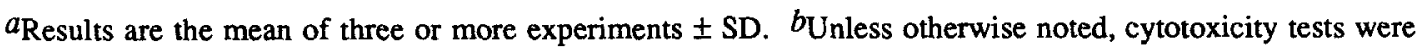
performed in $\mathrm{KB}$ cells as described in Ref. 24. $c ">$ " indicates IC 50 concentration not reached at highest concentration tested. $d_{\text {Ref. } 11}$ e Cytotoxicity determined in L1210 cells. $f_{\text {Ref. }} 15 . g$ Visual cytotoxicity in HFF cells. $h_{\text {Ref. } 14 .}{ }^{i}$ Average of $>50$ experiments. SI: selectivity index-C $\mathrm{C}_{50} / \mathrm{IC}_{50}$. 
base, and the thiosangivamycin analogs (10 a-c) were also prepared from the appropriate nitrile $(\mathbf{8})$ in methanolic sodium sulfide in a sealed vessel at $95^{\circ} \mathrm{C}$ in $80-95 \%$ yields.

Compounds $\mathbf{8 a}-\mathbf{c}, \mathbf{9 a - c}$ and $\mathbf{1 0 a - c}$ were evaluated for activity against HCMV by a plaque reduction assay ${ }^{9}$ in human foreskin fibroblasts (HFF cells), and the cytotoxicity of each compound in uninfected cells was determined by examining the effects on the growth of KB cells. ${ }^{24}$ The results are presented in Table I. Antiviral and cytoxicity data for the ribosyl, hydroxyethoxymethyl and dihydroxypropoxymethyl substituted pyrrolopyrimidines are presented for comparison. The data confirm that the major factor required for the antiviral activity of these 7-substituted 4-aminopyrrolo-[2,3-d]pyrimidines is the thioamide moiety at the 5position $\left(R_{1}\right)$, and that the hydroxyl group of 3 or 4 is not necessarily required for the compound to have activity against HCMV. As with the acyclic analogs, ${ }^{11,15}$ the non-nucleoside analogs of toyocamycin $(8 \mathbf{a}-\mathrm{c})$ and sangivamycin (9a-c) were non-toxic and relatively inactive against HCMV. In general, the thioamides were more toxic than the carboxamides which, in turn, were more toxic than the corresponding nitriles. Although the potency of compounds 10a-c against HCMV is greater than that of $\mathbf{4}$, the toxicity in uninfected cells also was greater. Therefore, the selectivity index for analogs 10a-c remain essentially the same when compared to that of the parent compound 4 (therapeutic ratios of $9-14$ vs 13 , respectively). The separation of cytotoxicity from antiviral activity, though, is greater for compounds $\mathbf{1 0 a - c}$ when compared to that of thiosangivamycin (3), indicatıng viral selectivity.

In summary, the design, synthesis and antiviral evaluation of several non-nucleoside pyrrolo[2,3-d]pyrimidines was examined. This study was initiated to investigate the possibility that a side chain hydroxyl group of analogs with known activity against HCMV, such as compounds 3 or 4 , may not be required for biological activity. The data herein suggest that the thioamide moiety provides antiviral activity without the requirement for phosphorylation of a side chain hydroxyl group. Since the activity of these compounds is mediated via a unique mechanism, biological studies to elucidate the mechanism of action are underway. We are expanding our studies with this class of compounds by making several selective alkyl and aryl substitutions at the 7-position of the base as well as examining modifications at other sites on the heterocycle with the initial goal of increasing the therapeutic index.

Acknowledgements: The authors would like to thank Dr. Reza M. Nassiri, Jack Hinkley and Eric E. Swayze for their helpful discussions regarding this work. We also thank Rae Herrst for preparation of the manuscript. This study was supported by the Department of Health and Human Services under Contract AI72641 from the National Institute of Allergy and Infectious Diseases.

\section{References and Notes:}

1) Bowden, R.A. Transplant. Proc, 1991, 23, 136.

2) Mills, J. and Masur, H. Sci. American 1990, 263, 50. 
3) Collaborative DHPG treatment study group. N. Engl.J. Med. 1986, 314, 801.

4) Palestine, A.G.; Polis, M.A.; Smet, M.D.; Baird, B.F.; Falloon, J.; Kovacs, J.A.; Davey, R.T.; Zurlo, J.J.; Zunich, K.M.; Davis, M.; Hubbard, L.; Brothers, R.; Ferris, F.L.; Chew, E.; Davis, J.L.; Rubin, B.I.; Mellow, S.D.; Metcalf, J.A.; Mansichewitz, J.; Minor, J.R.; Nussenblatt, R.B.; Masur, H. and Lane, C. Ann. of Intern. Med. 1991, 115, 665 .

5) Shepp, D.H.; Dandliker, P.S.; de Miranda, P.; Burnetle, T.; Cederberg, D.M.; Kirk L.E. and Meyers, J.D. Ann. Intern. Med. 1985, 103, 368.

6) Jacobson, M.A.; Gambertoglio, J. G.; Aweeka, F.T.; Causey, D.M. and Portale, A.A. J. Clin. Endo. Metabol. 1991, 72, 1130.

7) Stanat, S.C.; Reardon, J. E.; Erice, A.; Jordan, M.C.; Drew, W.L. and Biron, K.K. Antimicrob. Agents Chemother. 1991, 35, 2191.

8) Sullivan, V. and Coen, D. J. Jnfec. Dis . 1991, 164, 781.

9) Turk, S.R.; Shipman, C. Jr.; Nassiri, M.R.; Genzlinger, G.; Krawczyk, S.H.; Townsend, L.B. and Drach, J.C. Antimicrob. Agents Chemother. 1987, 31, 544.

10) For thiosangivamycin: See Table $I$.

11) Gupta, P.K.; Daunert, S.; Nassiri, M.R.; Wotring, L.L.; Drach, J.C. and Townsend, L.B. J. Med. Chem. 1989, 32, 402 .

12) Glazer, R.I. and Peale, A.L. Biochem. Pharmacol. 1980, 29, 305.

13) Miller, R. L.; Adamczyk, D. L.; Miller, W. H.; Koszalka, G. W.; Rideout, J. L.; Beacham, L. M.; Chao, E. Y.; Haggerty, J. J.; Krenitsky, T. A. and Elion, G. B. J. Biol. Chem. 1979, 254, 2346.

14) Renau, T.E.; Nassiri, M.R.; Swayze, E.E.; Townsend, L.B. and Drach, J.C. Antiviral Res. 1992, $19,15$.

15) Gupta, P.K.; Nassiri, M.R.; Coleman, L.A.; Wotring, L.L.; Drach, J.C. and Townsend, L.B. J. Med. Chem. 1989, 32, 1420.

16) For a review see: Townsend, L.B.; Drach, J. C; Wotring, L. L.; Vittori, S.; Pudlo, J. S.; Swayze, E. E.; Gupta, P.; Maruyama, T.; Saxena, N.; Coleman, L.; Westerman, A. C.; Spurr, J.; Nassiri, M. R.; Turk, S. R. and Krawczyk, S. H. Il Farmaco, 1991, 46, 113.

17) Smee, D.F.; McKernan, P.A.; Alaghamandan, H.A.; Frank, K.B.; Ramasamy, K.; Revankar, G.R. and Robins, R.K. Antiviral Res. 1988, 10, 263.

18) De Clerq, E.; Balzarini, J.; Madej, D.; Hansske, F. and Robins, M. J. Nucleic acid related compounds. 51. J. Med. Chem. 1987, 30, 481.

19) Kelley, J. L.; Linn, J.A.; Krochmal, M.P. and Selway, J.W.T. J. Med. Chem. 1988, 31, 2001.

20) Tanaka, H.; Baba, M.; Saito, S.; Miyasaka, T.; Takashima, H.; Sekiya, K.; Ubasawa, M.; Nitta, I.; Walker, R.T.; Nakashima, H. and De Clercq, E. I. Med. Chem. 1991, 34, 1508.

21) Smee, D.F.; Bartlett, M.L.; Alaghamandan, H.A.; Jones, M.M.; Revankar, G.R. and Robins, R.K. Antiviral Res. 1990, 13,1.

22) Melting point, ${ }^{1} \mathrm{H}$ NMR, Infrared and elemental analysis data for compounds $7,8,9$ and 10 are available from the authors upon request. 
23) Swayze, E.E.; Hinkley, J.M. and L.B. Townsend. In: L.B. Townsend and R.S. Tipson (Eds), Nucleic acid chemistry; improved and new synthetic procedures, methods and techniques, Part IV, 1991, pp. 16-18. WileyInterscience, New York.

24) Prichard, M. N.; Prichard, L. E.; Baguley, W. A.; Nassiri, M. R. and Shipman, C. Jr. Antimicrob. Agents Chemother. 1991, 35, 1060. 